\title{
Influence of Binders and Lightweight Aggregates on the Properties of Cementitious Mortars: From Traditional Requirements to Indoor Air Quality Improvement
}

\author{
Chiara Giosuè ${ }^{1}$ (D), Mattia Pierpaoli ${ }^{1}$, Alessandra Mobili ${ }^{1}$ (D), Maria Letizia Ruello ${ }^{1}$ (ID) and \\ Francesca Tittarelli 1,2,* \\ 1 Department of Materials, Environmental Sciences and Urban Planning (SIMAU), Università Politecnica \\ delle Marche, 60131 Ancona, Italy; c.giosue@univpm.it (C.G.); m.pierpaoli@pm.univpm.it (M.P.); \\ a.mobili@univpm.it (A.M.); m.l.ruello@univpm.it (M.L.R.) \\ 2 Institute of Atmospheric Sciences and Climate, National Research Council (ISAC-CNR), 40129 Bologna, Italy \\ * Correspondence: f.tittarelli@univpm.it
}

Received: 15 July 2017; Accepted: 18 August 2017; Published: 22 August 2017

\begin{abstract}
Innovative and multifunctional mortars for renders and panels were manufactured using white photocatalytic and non-photocatalytic cement as binder. Unconventional aggregates, based on lightweight materials with high specific surface and adsorbent properties, were adopted in order to investigate the possible ability to passively improve indoor air quality. The reference mortar was manufactured with traditional calcareous sand. Results show that even if the mechanical properties of mortars with unconventional aggregates generally decrease, they remain acceptable for application as render. The innovative mortars were able to passively improve indoor air quality in terms of transpirability (70\% higher), moisture buffering ability (65\% higher) and depolluting capacity (up to $75 \%$ higher) compared to traditional ones under the current test conditions.
\end{abstract}

Keywords: mortar; cement; lightweight aggregates; Indoor Air Quality (IAQ); depollution; moisture buffering value

\section{Introduction}

The impact of the building sector in terms of global energy consumption is about $40 \%$ [1]. Therefore currently in this sector, laws and regulations are stricter in terms of energy efficiency: buildings are more air-tied and the indoor air quality (IAQ) worsens inevitably [2]. On the other hand, in recent decades, changes in lifestyle have led people to spend $70-90 \%$ of their time indoors [3] where they often come into contact with an unhealthy environment. Occupants are potentially exposed to airborne pollutants such as Volatile Organic Compounds (VOCs), anhydrides $\left(\mathrm{NO}_{\mathrm{x}}, \mathrm{SO}_{\mathrm{x}}\right)$, and ozone $\left(\mathrm{O}_{3}\right)$ [4] which can have both short- and long-term effects on human health, leading to the well-known Sick Building Syndrome (SBS).

Also, non-adequate levels of Relative Humidity (RH) have negative effects on the comfort and well-being of the occupants. The optimal RH level is about 50\% [5]: $\mathrm{RH}$ levels below $25 \%$ cause discomfort and drying of the mucous membranes and skin [6], high RH levels cause discomfort and favour biological growth [7-9].

Conventionally, the broad strategies to reduce indoor pollutants or to modulate $\mathrm{RH}$ are: source control, dilution by active engineered control systems (Heating, Ventilation and Air-ConditioningHVAC) and stand-alone air purifiers [10]. Source control is very difficult since the occupants and furnishings are sources themselves. Active systems require energy to function affecting energy 
consumption in buildings. Building materials such as mortars, plasters and finishes, thanks to their high surface in indoor applications, can interact with the indoor microclimate as passive systems, increasing IAQ without energy demand [11-14].

Depolluting properties of building materials can be due to their adsorption capacity and/or to their photocatalytic activity (PCA). Cementitious materials enriched with $\mathrm{TiO}_{2}$ in bulk [15] or as coating [16,17] show self-cleaning [18] and depolluting properties thanks to the photocatalytic effect of $\mathrm{TiO}_{2}$ under UV irradiation. Horgnies et al. (2012) described how the addition of a low quantity of activated carbon in a photocatalytic cementitious matrix can enhance the decomposition of $\mathrm{NO}_{\mathrm{x}}$, improving the adsorptive phase of the process [19]. For indoor applications, Vieira et al. (2014) added commercial mortars with $\mathrm{TiO}_{2}$, superabsorbent polymers and Phase Changing Materials (PCMs) to improve the depolluting properties, Moisture Buffering Capacity (MBC) and thermal insulation [13]. The authors studied that the application of a $\mathrm{TiO}_{2}$-based paint on different support materials enhances the degradation of NO and selected VOCs [20]. Tittarelli et al. (2015) and Giosuè et al. (2016) investigated the ability of mortars to passively improve indoor comfort and health, in terms of indoor pollutants adsorption and $\mathrm{MBC}$, by using unconventional adsorbent aggregates and biomass waste materials [21,22].

In the current research, the aim was to investigate the effect of using both unconventional adsorbent aggregates and a cementitious photocatalytic binder on the ability of the mortars to passively improve indoor comfort and health. The transport of the pollutant over the activated catalyst surface is the first step of heterogeneous photocatalysis. By using an adsorbent material as aggregate, the pollutant concentration in the proximity of the catalyst is increased, perhaps enhancing the photocatalytic efficiency. For this purpose, sixteen types of mortars were manufactured with three different adsorbent aggregates, using both a white photocatalytic and non-photocatalytic cement, as reference. A commercial calcareous sand was used as reference aggregate. Mortars were compared in terms of mechanical strength, capillary water absorption, shrinkage, water vapour permeability, MBC and depolluting properties. Since water promotes degradation of building materials, with a consequent increase of maintenance costs, hydrophobic agents are often adopted in mortar formulations to improve durability, due to their ability to make concrete less susceptible to water saturation [23]: the possible effect of a hydrophobic admixture on mortar properties was also investigated.

\section{Materials}

\subsection{Binders}

White cement CEM II A/LL $42.5 \mathrm{R}$ (C) was used as a reference binder. White photocatalytic cement (PC), thanks to its patented photocatalytic admixture [24,25], of the same class strength was used as a photocatalytic binder.

\subsection{Aggregates}

The adopted unconventional aggregates, indicated as A1, A2, A3, are lightweight materials generally used as adsorbent for heavy metals, dyes, oil, and molecular sieves in gas separation processes. A1 and A2 are polar adsorbents, while A3 is a non-polar adsorbent. Table 1 compares their physical properties, obtained by data sheets and laboratory tests, with those of a natural commercial sand used as reference. Figure 1 provides the particle size distribution curves of aggregates obtained by sieving. 


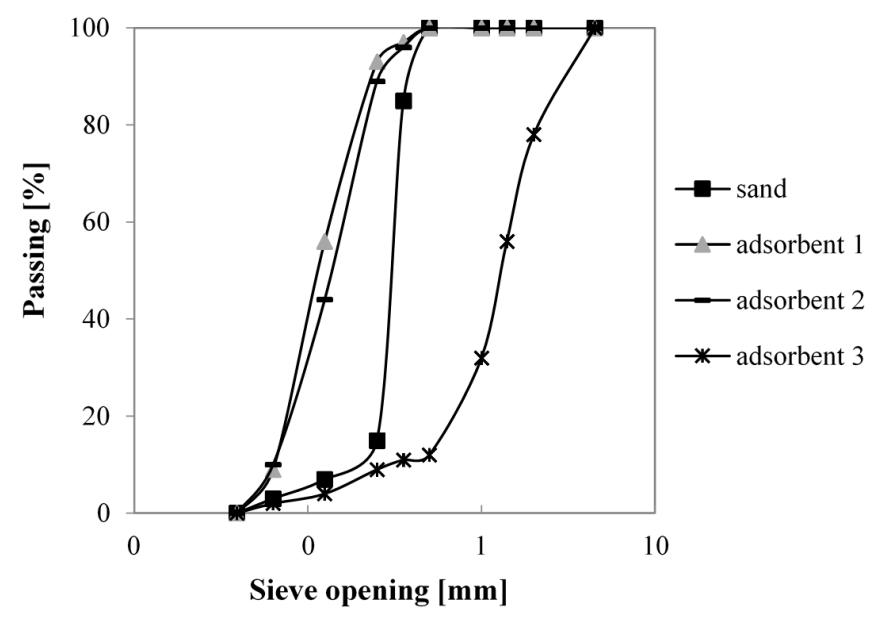

Figure 1. Grain size distribution curves of aggregates.

Table 1. Properties of aggregates.

\begin{tabular}{ccccc}
\hline Aggregate & Code & Specific Surface $\left(\mathbf{m}^{\mathbf{2}} \mathbf{/ g}\right)$ & Density $\left.\mathbf{s s d} * \mathbf{( k g} / \mathbf{m}^{\mathbf{3}}\right)$ & Water Absorption after $\mathbf{2 4} \mathbf{~} \mathbf{~ ( \% )}$ \\
\hline Sand & S & 5 & 2650 & 5 \\
Adsorbent 1 & A1 & 600 & 1600 & 22 \\
Adsorbent 2 & A2 & 750 & 1310 & 86 \\
Adsorbent 3 & A3 & 900 & 1180 & 31 \\
\hline
\end{tabular}

* ssd: saturated surface dried condition.

\subsection{Admixtures}

A hydrophobic admixture (h), based on a $45 \%$ water solution of butyl-ethoxy-silane was added during the cast at the dosage of $1.2 \%$ by binder weight in some mixtures in order to have a hydrophobic bulk mortar.

\subsection{Mix Design}

Table 2 shows the mix proportions of mortars. The dosages of aggregates are reported in saturated surface dried (ssd) condition. Reference mortars were manufactured with cement (white and photocatalytic) and commercial sand (C-S and PC-S), with (h) and without hydrophobic admixture. Mortars have a water to binder ratio $(\mathrm{w} / \mathrm{b})$ of 0.5 by weight and an aggregate to binder ratio $(\mathrm{a} / \mathrm{b})$ of 3.5 by volume. The tested mortars were manufactured by replacing $100 \%$ sand volume with different unconventional aggregates. Before casting, aggregates were water pre-soaked till constant mass was achieved.

Table 2. Mix proportions $\left(\mathrm{kg} / \mathrm{m}^{3}\right)$ and workability of mortars.

\begin{tabular}{cccccccccc}
\hline Mix & Water & $\begin{array}{c}\text { White } \\
\text { Cement }\end{array}$ & $\begin{array}{c}\text { Photocatalytic } \\
\text { Cement }\end{array}$ & S & A1 & A2 & A3 & $\begin{array}{c}\text { Hydrophobic } \\
\text { Admixture }\end{array}$ & $\begin{array}{c}\text { Slump } \\
(\mathbf{m m})\end{array}$ \\
\hline C-S & 256 & 512 & - & 1535 & - & - & - & - & 120 \\
C-S h & 253 & 512 & - & 1535 & - & - & - & 6 & 115 \\
PC-S & 256 & - & 512 & 1535 & - & - & - & - & 120 \\
PC-S h & 253 & - & 512 & 1535 & - & - & - & 6 & 115 \\
C-A1 & 256 & 512 & - & - & 927 & - & - & - & 108 \\
C-A1 h & 253 & 512 & - & - & 927 & - & - & 6 & 107 \\
PC-A1 & 256 & - & 512 & - & 927 & - & - & - & 106 \\
PC-A1 & 253 & - & 512 & - & 927 & - & - & 6 & 106 \\
h & 256 & 512 & - & - & - & 759 & - & - & 128 \\
C-A2 & 256 &
\end{tabular}


Table 2. Cont.

\begin{tabular}{|c|c|c|c|c|c|c|c|c|c|}
\hline Mix & Water & $\begin{array}{l}\text { White } \\
\text { Cement }\end{array}$ & $\begin{array}{c}\text { Photocatalytic } \\
\text { Cement }\end{array}$ & $S$ & A1 & A2 & A3 & $\begin{array}{l}\text { Hydrophobic } \\
\text { Admixture }\end{array}$ & $\begin{array}{l}\text { Slump } \\
(\mathrm{mm})\end{array}$ \\
\hline C-A2 h & 253 & 512 & - & - & - & 759 & - & 6 & 122 \\
\hline PC-A2 & 256 & - & 512 & - & - & 759 & - & - & 124 \\
\hline $\begin{array}{c}\text { PC-A2 } \\
\mathrm{h}\end{array}$ & 253 & - & 512 & - & - & 759 & - & 6 & 128 \\
\hline C-A3 & 256 & 512 & - & - & - & - & 683 & - & 110 \\
\hline C-A3 h & 253 & 512 & - & - & - & - & 683 & 6 & 110 \\
\hline PC-A3 & 256 & - & 512 & - & - & - & 683 & - & 110 \\
\hline $\begin{array}{c}\text { PC-A3 } \\
\text { h }\end{array}$ & 253 & - & 512 & - & - & - & 683 & 6 & 111 \\
\hline
\end{tabular}

\section{Methods}

\subsection{Workability}

The mortar workability was measured by flow table, according to UNI EN 1015-3:2007.

\subsection{Mechanical Properties}

Compressive strength $\left(R_{c}\right)$ tests were carried out according to the Italian standard UNI EN 1015-11:2007 on at least three prisms $(40 \times 40 \times 160 \mathrm{~mm})$ cured at $\mathrm{T}=20 \pm 2{ }^{\circ} \mathrm{C}$ and $\mathrm{RH}=95 \pm 3 \%$ for 7 days and then at $\mathrm{T}=20 \pm 2{ }^{\circ} \mathrm{C}$ and $\mathrm{RH}=65 \pm 3 \%$ for the following 21 days. A 'Galdabini' hydraulic press with a precision of $1 \%$ was used. The average results are reported.

After 28 days of curing, the density $\left(\rho\right.$, in $\left.\mathrm{kg} / \mathrm{m}^{3}\right)$ of hardened mortars was calculated and the specific strength, one of the most common parameters used for comparing materials [26], was evaluated as $R_{s c}=R_{c} / \rho\left(\mathrm{Pa} /\left(\mathrm{kg} / \mathrm{m}^{3}\right)\right)$.

From the results of compressive strength, Elastic modulus $E_{c}$ was evaluated according to the empirical relation suggested by the ACI Committee (ACI 318-95) [27] $E_{c}=4.73\left(f_{c}\right)^{1 / 2}(\mathrm{GPa})$, where $f_{c}$ is the cylindrical compressive strength of mortars evaluated with the relation $f_{c}=0.83 \cdot R_{c}$, proposed by [28].

\subsection{Microstructure: Morphology and Pore Size Distribution}

In order to correlate macroscopic properties with microstructure, the morphology of specimens was investigated by Scanning Electron Microscopy (SEM); a ZEISS 1530 SEM (Carl Zeiss, Oberkochen, Germany) equipped with a Schottky emitter, with two different secondary electrons (SE) detectors (the in-lens and the Everhart-Thornley) and operating at $10 \mathrm{keV}$ was used. Two small mortar fragments of about $1 \mathrm{~cm}^{3}$ were collected from each specimen and covered with a thin layer of graphite to make them conductive before one observation. The most representative SEM images of the mortars were then reported.

Moreover, in cementitious mortars the porosity can be divided in: (a) gel pores-nano-pores inside the hydration products, with pore diameter of about $0.5-10 \mathrm{~nm}$; (b) capillary pores-micro-pores between the hydration products, with pore diameter between $10 \mathrm{~nm}$ and $1 \mu \mathrm{m}$, strongly dependent on the hydration degree and the $\mathrm{w} / \mathrm{b}$; (c) macro pores-pores due to entrained air with spherical micro-bubbles, with pore diameters higher than $10 \mu \mathrm{m}$ and (d) porosity into the aggregate [28].

In this case, aggregate porosity strongly influences the properties of mortars; the unconventional aggregates have additional nano porosity compared to conventional sand. The effect of unconventional lightweight aggregates on the pore size distribution of mortars was studied by Mercury Intrusion Porosimetry (MIP) with Mercury Porosimeter PASCAL 240 (Thermo Fisher Scientific, Waltham, MA, USA). For each mortar typology, three small mortar fragments of about $1 \mathrm{~cm}^{3}$ were tested after 28 days of curing and the average results are reported. 


\subsection{Drying Shrinkage}

Mortars applied in an environment at $\mathrm{RH}<95 \%$ are subjected to drying shrinkage. The free drying shrinkage of different mortars was measured according to UNI EN 12617-4:2003.

Three prismatic specimens $(40 \times 40 \times 160 \mathrm{~mm})$ were cured at $\mathrm{T}=20 \pm 2{ }^{\circ} \mathrm{C}$ and $\mathrm{RH}=95 \pm 3 \%$ for the first $24 \mathrm{~h}$. Immediately after demoulding, the initial length of the sample was recorded and then exposed at $\mathrm{T}=20 \pm 2{ }^{\circ} \mathrm{C}$ and $\mathrm{RH}=50 \pm 5 \%$. Sample length and weight were recorded for at least 40 days by using a comparator with a measuring accuracy of $0.001 \mathrm{~mm}$ and a scale with an accuracy of $0.01 \mathrm{~g}$, respectively. The average results are reported.

\subsection{Capillary Water Absorption}

Capillary water transports aggressive agents and deteriorates mortars [29] therefore the study of capillary water absorption is of primary importance to test the durability of a construction material.

The capillary water absorption of mortars is measured according to UNI EN 1015-18:2004. Three test specimens were obtained by prisms $(160 \times 40 \times 40 \mathrm{~mm})$ broken into two halves, and cured as described in Section 3.2. Specimens were placed in a box, semi-immersed in water at a depth of 5 to $10 \mathrm{~mm}$, by keeping constant the level of water during the test. The box was kept closed to prevent water evaporation. Specimens were removed from the box after $10 \mathrm{~min}$, the surface was quickly dried with a moist fabric to remove the excess of water and then specimens were weighed and immediately placed back into the box. The procedure was repeated after $90 \mathrm{~min}$. The capillary water absorption coefficient $(C)$ of mortar is the average between the specimens and it is calculated according to the standard.

\subsection{Water Vapour Permeability}

Mortars and renders should have a good water vapour permeability to facilitate the drying process of the masonry assemblage, as well as the disposal of water vapour produced inside buildings [30].

Water vapour permeability measurements are carried out according to the UNI EN 1015-19:2007 and data processed according to UNI EN ISO 12572:2007. Three cylindrical mortar specimens $(\mathrm{d}=12.5 \mathrm{~cm} ; \mathrm{h}=3.0 \mathrm{~cm})$, cured as described in Section 3.2, were placed on the top of a sample-holder with a saturated solution of potassium nitrate $\left(\mathrm{KNO}_{3}\right)$ inside $\left(\mathrm{RH}=93 \pm 3 \%\right.$ at $\left.\mathrm{T}=20 \pm 2{ }^{\circ} \mathrm{C}\right)$. The containers were placed in a climatic chamber at $\mathrm{T}=20 \pm 2{ }^{\circ} \mathrm{C}$ and $\mathrm{RH}=50 \pm 5 \%$ and the test started. On the side surface, the specimens were sealed with a non-breathable film in order to guarantee the unidirectional flow of the water vapour from inside to outside, due to the difference of RHs. The mass of the specimens was monitored day by day until stationary conditions were achieved. The average results of the test are reported in terms of the water vapour diffusion resistance factor, $\mu$. $\mu$ is defined as the ratio between the vapour permeability of stagnant air $\delta_{a}(\mathrm{~kg} /(\mathrm{Pa} \mathrm{m} \mathrm{s}))$ and the vapour permeability of the material $\delta_{p}(\mathrm{~kg} /(\mathrm{Pa} \mathrm{m} \mathrm{s}))$ at the same temperature and pressure [31].

\subsection{Moisture Buffering Capacity}

Indoor environments are subjected to quick changes in $\mathrm{RH}$ and building materials should act as a buffer for moisture. The Moisture Buffering Capacity (MBC) is the capacity of a material to absorb and release moisture from/to the environment where it is placed [32].

In this paper, the influence of unconventional aggregates on MBC of mortars is assessed by a simplified version of the NORDTEST method [33] where specimens are cyclically exposed to different RHs for fixed periods. Three cylindrical specimens $(\mathrm{d}=10.0 \mathrm{~cm}, \mathrm{~h}=3.0 \mathrm{~cm})$ were manufactured and cured as described in Section 3.2. Before testing, specimens were pre-conditioned in a climate chamber at $\mathrm{T}=20 \pm 2{ }^{\circ} \mathrm{C}$ and $\mathrm{RH}=50 \pm 3 \%$ until constant weight was achieved. In order to enhance the aggregate contribution to the moisture buffering properties of mortars, the specimens were superficially abraded and cleaned with compressed air before testing. 
Specimens were exposed to cyclic step-changes that alternate high levels ( $75 \%$ for $8 \mathrm{~h}$ ) and low levels ( $33 \%$ for $16 \mathrm{~h}$ ) of RH. The test simulates daily variations. The exposure to the two different RHs was carried out by putting the specimens inside two climate boxes, respectively containing a saturated solution of magnesium chloride $\left(\mathrm{MgCl}_{2}, \mathrm{RH}=33 \%\right)$ and sodium chloride $(\mathrm{NaCl}, \mathrm{RH}=75 \%)$. The boxes were kept inside a climatic chamber to maintain the temperature constant at $\mathrm{T}=20 \pm 2{ }^{\circ} \mathrm{C}$ during the test. The duration of the entire cycle was $24 \mathrm{~h}$. The amount of water vapour absorbed or released by the specimens during each step was determined by measuring the weight of the specimens before changing boxes [21].

The practical Moisture Buffering Value $(M B V)\left(\mathrm{g} /\left(\mathrm{m}^{2} \% \mathrm{RH}\right)\right)$ is calculated as the amount of moisture changed by the material per surface unit and RH gradient, as indicated in [34].

\subsection{Depolluting Properties}

Depolluting properties of different mortars were evaluated by two different tests. The first one consists of a continuous flow test and the second one is a batch test, respectively to investigate the photocatalytic activity towards the nitrogen oxide (NO) removal and the VOC. Also in this case, in order to enhance the aggregate contribution on the depolluting properties, the specimens were superficially abraded and cleaned before testing.

\subsubsection{Continuous Flow Test}

In the continuous flow test, nitrogen oxide (NO) was chosen as a model of air pollutants. NO is commonly found in indoor air. The photochemical smog reactions result from the interaction of various pollutants such as $\mathrm{NO}_{\mathrm{x}}$ and/or VOCs in the presence of sunlight.

For this reason, anthropogenic $\mathrm{NO}_{\mathrm{x}}$ emission constitutes a wider problem in indoor conditions than in outdoor ones and its removal is considered beneficial to prevent the formation of secondary pollutants [25].

The continuous flow test was performed according to the procedure provided by the Italian standard UNI 11247:2010. The specimen (cylinder with $\mathrm{d}=9 \mathrm{~cm}$ and cured as described in Section 3.2) was placed inside a borosilicate glass chamber of $3.58 \mathrm{~L}$ on a tripod in order to irradiate the surface with UVA radiation provided by an UVA metal-halogen quartz lamp with mercury vapour, peak at $360 \mathrm{~nm}$ and adsorbed power of $400 \mathrm{~W}$. The distance between the surface of the sample and the lamp guarantees a specimen radiance of $20 \mathrm{~W} / \mathrm{m}^{2}$ (photoradiometer HD2102.2, with a probe centered in the field of UVA, Delta OHM, Padova, Italy). The inlet gas was a mixture of synthetic air and NO. The chamber was linked to a nitrogen oxides analyser. The NO inlet concentration was $500 \mathrm{ppb}$ (flux of $1.5 \mathrm{~L} \cdot \mathrm{min}^{-1}$ ) and the abatement coefficient $A_{\mathrm{C}}$, in terms of the percentage of abated $\mathrm{NO}$, was evaluated according to the standard.

\subsubsection{In-Batch Test}

In the adsorption test, methyl-ethyl-ketone (MEK) is chosen as model of air pollutants (VOCs) for its environmental stability. This compound is an irritant for human eyes and nose and harmful health effects occur at high concentrations, Threshold Limit Value $(\mathrm{TLV})=200 \mathrm{ppm}=590 \mathrm{mg} / \mathrm{m}^{3}$. The MEK vapour pressure is $95.1 \mathrm{mmHg}$ at $\mathrm{T}=25^{\circ} \mathrm{C}$. It has an odour threshold of $5.4 \mathrm{ppm}$, corresponding to $16 \mathrm{mg} / \mathrm{m}^{3}$ [35].

The concentration of MEK in a $16.65 \mathrm{~L}$ sealed borosilicate glass box containing the specimen was monitored over time [21]. Inside the test box a fan guarantees continuous air recirculation. The specimens are cylindrical $(\mathrm{d}=3.4 \mathrm{~cm}, \mathrm{~h}=4 \mathrm{~cm})$ and cured as described in Section 3.2. Air samples inside the box were collected by a micro-syringe and analysed with a gas chromatograph (Flame Ionization Detector, injector split 1:15, carrier flow $2 \mathrm{~mL} / \mathrm{min}$, capillary column, $25 \mathrm{~m} \times 0.32 \mathrm{~mm}$, $0.52 \mu \mathrm{m}$ cross linked methyl siloxane, isotherm condition $40^{\circ} \mathrm{C}$ ). The MEK injected into the test box was initially $50 \mu \mathrm{L}$ corresponding to $2402 \mathrm{mg} / \mathrm{m}^{3}$ (approximately 4 times TLV). Three measurements were repeated and the average results of the test are reported. The data starts to be consistent $20 \mathrm{~min}$ 
after the initial injection when all MEK has been vaporised. Then, the results were plotted as a percentage of detected concentration $\left(C_{i}\right)$ divided by to the initial concentration $\left(C_{0}\right)$. Tests were carried out under two different conditions: under dark conditions and under $10 \mathrm{~W} / \mathrm{m}^{2}$ UVA radiation on the surface of the specimens.

\section{Results and Discussion}

\subsection{Workability}

Slump values are shown in Table 2. The use of unconventional aggregates in ssd condition instead of conventional sand permits mortars to be obtained with the same stiff workability, according to UNI EN 1015-6:2007, since the slump flow is always lower than $140 \mathrm{~mm}$, with no evidence of segregation. Also, the hydrophobic admixture does not affect workability.

\subsection{Mechanical Properties}

Results are shown in Table 3. The use of different binders does not imply differences in compressive strength results. As already reported in the literature, a slight decrease in compressive strength is generally observed with the addition of a hydrophobic admixture [36,37].

Table 3. Mechanical properties of mortars: compressive strength $\left(R_{c}\right)$, hardened density $(\rho)$, compression specific strength $\left(R_{s c}\right)$, and Elastic modulus $\left(E_{c}\right)$ after 28 days of curing.

\begin{tabular}{ccccc}
\hline Mix & $\boldsymbol{R}_{\boldsymbol{c}}(\mathbf{M P a})$ & $\boldsymbol{\rho}\left(\mathbf{k g} / \mathbf{m}^{3}\right)$ & $\boldsymbol{R}_{\boldsymbol{s c}}\left(\mathbf{P a} /\left(\mathbf{k g} / \mathbf{m}^{3}\right)\right)$ & $\boldsymbol{E}_{\boldsymbol{c}}(\mathrm{GPa})$ \\
\hline C-S & $31.2 \pm 1.0$ & $2091 \pm 63$ & 14.92 & 22.76 \\
C-S h & $29.2 \pm 1.7$ & $2069 \pm 84$ & 14.11 & 22.02 \\
PC-S & $31.0 \pm 0.5$ & $2141 \pm 52$ & 14.48 & 22.69 \\
PC-S h & $28.9 \pm 1.2$ & $2092 \pm 49$ & 13.81 & 21.91 \\
C-A1 & $32.9 \pm 2.1$ & $1677 \pm 32$ & 19.62 & 23.37 \\
C-A1 h & $29.5 \pm 1.8$ & $1621 \pm 21$ & 18.20 & 22.13 \\
PC-A1 & $30.9 \pm 0.5$ & $1670 \pm 27$ & 18.50 & 22.65 \\
PC-A1 h & $28.5 \pm 1.0$ & $1609 \pm 36$ & 17.71 & 21.76 \\
C-A2 & $6.6 \pm 0.3$ & $1223 \pm 13$ & 5.40 & 10.47 \\
C-A2 h & $4.6 \pm 0.1$ & $1192 \pm 22$ & 3.86 & 8.74 \\
PC-A2 & $5.0 \pm 0.3$ & $1202 \pm 23$ & 4.16 & 9.11 \\
PC-A2 h & $4.4 \pm 0.1$ & $1258 \pm 12$ & 3.50 & 8.55 \\
C-A3 & $16.4 \pm 1.0$ & $1350 \pm 51$ & 12.15 & 16.50 \\
C-A3 h & $16.7 \pm 0.8$ & $1304 \pm 25$ & 12.81 & 16.65 \\
PC-A3 & $18.1 \pm 0.5$ & $1353 \pm 31$ & 13.38 & 17.34 \\
PC-A3 h & $18.7 \pm 0.6$ & $1370 \pm 34$ & 13.65 & 17.62 \\
\hline
\end{tabular}

The main differences were measured with different aggregates. Mortars prepared with A2 aggregate show the lowest value of mechanical strength, about $80 \%$ lower than sand mortars. In the case of A3 mortars, the mechanical strength is about $45 \%$ lower than sand mortars due to the lowest density (Table 1). The best results are recorded by A1 mortars where values are even slightly higher $(5 \%)$ than those of the reference mortar, in spite of the significant (20\%) lower density compared to the reference. Being directly evaluated from the mechanical strength, the $E_{c}$ values show the same trend.

Thanks to the total replacement of calcareous sand volume with unconventional aggregate A2, lightweight mortars can be obtained. The value of the density is $\leq 1300 \mathrm{~kg} / \mathrm{m}^{3}$, which is the limit of classifying mortars as lightweight according to UNI EN 998-1:2010. A lightweight material is highly appreciated in non-structural applications, since it gives benefits in terms of the lower weight of the structure, higher sound absorption, and lower costs of buildings [38,39].

A3 mortars have the same $R_{s c}$ value as the reference mortar, A2 mortars have four times less specific resistance than sand mortars but, thanks to the increase in lightness, A1 mortars have about $35 \%$ higher value of $R_{S C}$ than the reference mortars. 
Also in this case, there are no relevant differences in using different binders or adding the hydrophobic admixture.

\subsection{Microstructure: Morphology and Pore Size Distribution}

Figure 2 reports the morphological observations obtained by SEM analysis of different mortars.
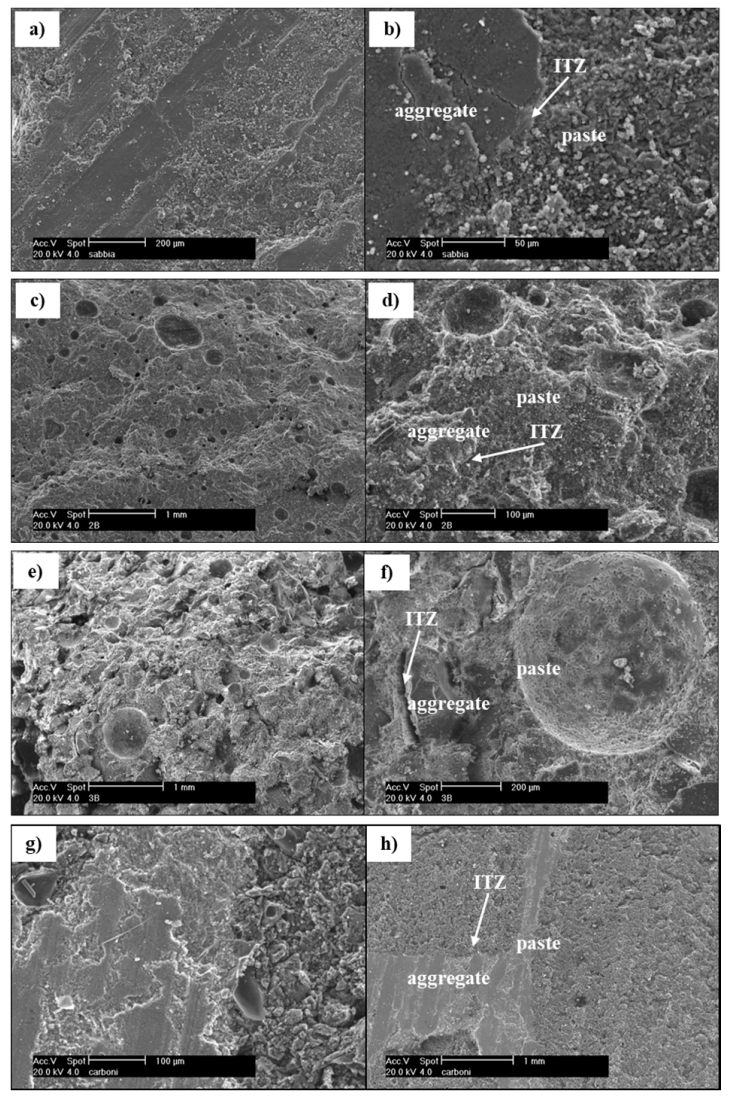

Figure 2. Scanning electron microscopy (SEM) images of mortars: (a,b) C-S; (c,d) C-A1; (e,f) C-A2; (g,h) C-A3.

The microstructure of the reference mortar (Figure 2a,b) appears homogeneous and dense. This, together with the high mechanical strength of calcareous sand and the good adhesion observed between sand and cementitious paste, explains the high mechanical performance of the reference mortar. In the case of A1 mortar (Figure 2c,d), the microstructure appears quite homogeneous and dense, even if some entrapped air bubbles are evident. However, the Interfacial Transition Zone (ITZ) between cement paste and A1 aggregate is detectable only with difficulty, meaning there is a good adhesion between aggregate and binder paste. This is probably due to the possible (at least superficially) pozzolanic reactivity of this unconventional aggregate with $\mathrm{Ca}(\mathrm{OH})_{2}$ of the cement paste, as already reported by other authors [39]. This justifies the high mechanical behaviour of this mortar, even compared to the conventional sand mortar, in spite of the higher lightness. When A2 aggregate is used (Figure 2e,f), the microstructure of mortar appears very heterogeneous and porous. Some entrapped air bubbles are evident and also the ITZ between A2 aggregate and cement paste is easily detectable meaning a poor adherence between the two components. This is most probably due to the smooth surface of this aggregate. These facts explain why A2 mortar shows the worst mechanical performances.

With $\mathrm{A} 3$ aggregate (Figure $2 \mathrm{~g}, \mathrm{~h}$ ), mortars have a quite porous but homogeneous microstructure. Moreover, the ITZ between A3 aggregate and cement paste is good. This explains why its mechanical 
strength is significantly higher compared to that of A2 mortars, even if still lower than that of the reference mortars.

Since the introduction of the hydrophobic admixture does not significantly change the mechanical strength of the materials, Table 4 and Figure 3 compare the results of MIP analysis obtained by all sand-based mortars and by unconventional aggregate mortars, but only without hydrophobic admixture.

The higher the specific surface of the unconventional adsorbent aggregate, the higher is the value of the mortar specific surface. This was verified only in A3 mortars; A3 aggregate has a high quantity of pores smaller than $0.01 \mu \mathrm{m}[40]$ and this range of porosity is too small to be detected by MIP.

Table 4. Total percentage of pores $(V p)$ and specific surface of mortars measured by mercury intrusion porosimetry (MIP).

\begin{tabular}{ccc}
\hline Mix & $\boldsymbol{V} \boldsymbol{p}(\mathbf{\%})$ & Specific Surface $\left(\mathbf{m}^{2} / \mathbf{g}\right)$ \\
\hline C-S & 21 & 7.36 \\
C-S h & 20 & 8.27 \\
PC-S & 20 & 7.54 \\
PC-S h & 21 & 8.08 \\
C-A1 & 36 & 39.88 \\
PC-A1 & 36 & 40.47 \\
C-A2 & 47 & 49.00 \\
PC-A2 & 52 & 56.11 \\
C-A3 & 25 & 6.69 \\
PC-A3 & 27 & 7.80 \\
\hline
\end{tabular}

Sand mortars have, as expected, the lowest percentage of voids (about 20\%). A3 mortars have about $25 \%$ more total porosity than the reference mortar. Despite A1 mortars showing the best compressive strength, the total pore volume of these mortars is about $36 \%, 75 \%$ higher than the sand mortars. As already explained, the optimum transition zone observed by SEM analysis (Figure 2c,d), and the possible pozzolanic activity explains their excellent mechanical behaviour. A2 mortars have the highest value of total porosity $(V p \sim 50 \%)$, more than two times higher than that measured in sand mortars. Together with the bad ITZ between A2 aggregate and cement paste observed by SEM images (Figure 2e,f), their higher porosity explains their low compressive strength.

a)

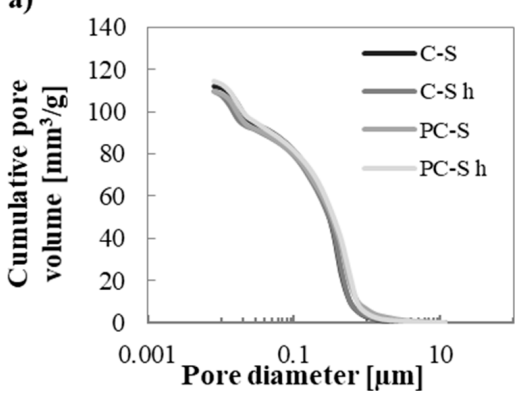

c)

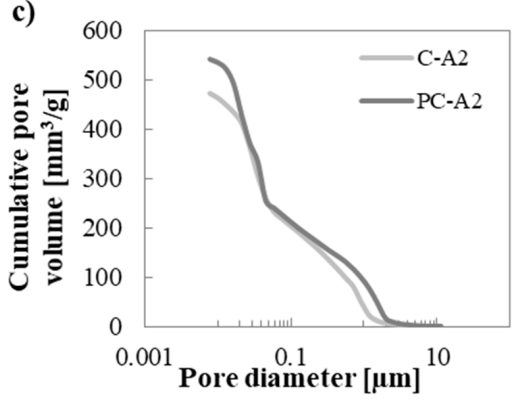

b)
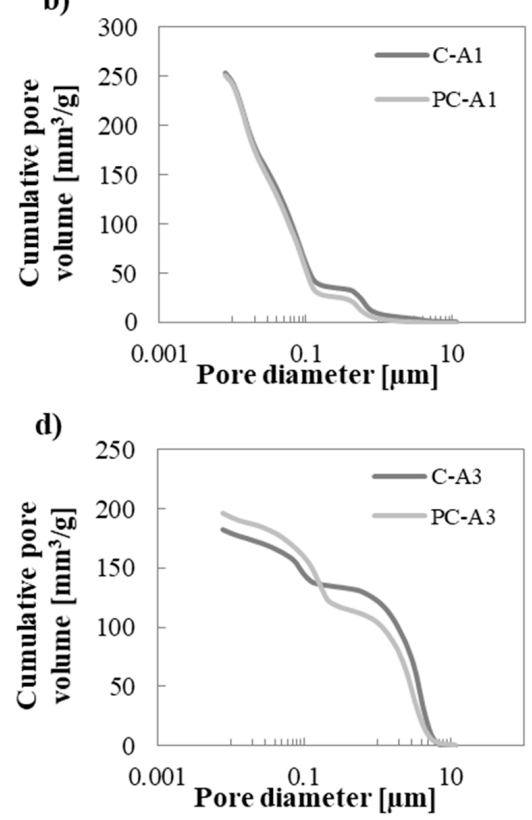

Figure 3. Cumulative pore volume distribution of mortars without hydrophobic admixture: (a) C-S, C-S h, PC-S, PC-S h; (b) C-A1, PC-A1; (c) C-A2, PC-A2; (d) C-A3, PC-A3. 
Figure 3 shows the MIP results in terms of cumulative pore volume distribution. The curves generally have a poly-modal distribution with two main bends: the first is around pore diameters of $0.430 \mu \mathrm{m}$, the second around pore diameters of $0.013 \mu \mathrm{m}$. The bend at the lower diameter is related to the paste because it is detected in all specimens; the second bend is characteristic of each aggregate. In case of A1 mortars, porosity distribution becomes tri-modal. Bends are at $0.43 \mu \mathrm{m}, 0.08 \mu \mathrm{m}$ and $0.01 \mu \mathrm{m}$, respectively. For A2 and A3, mortar bends are at $0.93 \mu \mathrm{m}$ and $0.21 \mu \mathrm{m}$ and $3.27 \mu \mathrm{m}$ and $0.1 \mu \mathrm{m}$, respectively.

The addition of the hydrophobic admixture does not generate differences in terms of pore size distribution. If the photocatalytic binder is used, pores are slightly shifted towards smaller diameters. Also in a previous study $[41,42]$, the introduction of $5 \%$ in weight of $\mathrm{TiO}_{2}$ in mortars shifted pores dimension to smaller values. This trend is not detected in A2 mortars, perhaps due to the high total porosity (Table 4 ) of the mortar itself, mostly introduced by the poor ITZ (Figure 2f).

\subsection{Drying Shrinkage}

Sand mortars have the lowest value of drying shrinkage and water loss (Figure 4); after seven days the specimens do not show significant length variation.
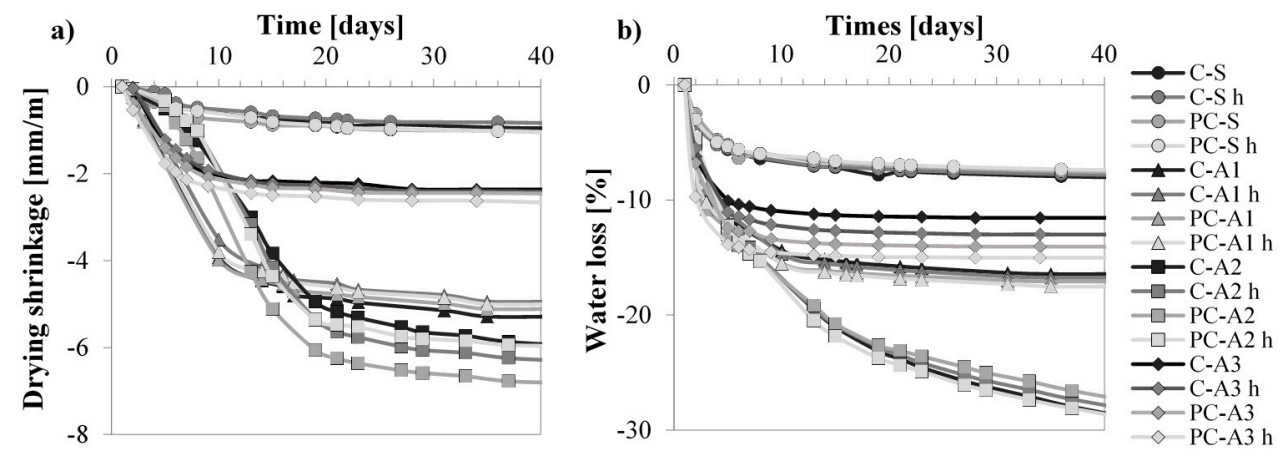

Figure 4. Mortars exposed at $\mathrm{RH}=50 \%$ and $\mathrm{T}=20^{\circ} \mathrm{C}$ : (a) drying shrinkage; (b) water loss.

In general, when sand is replaced by unconventional aggregates, the drying shrinkage is enhanced. The use of A3 implies 2.5 times higher values of shrinkage. When A1 and A2 are used, mortars shrink five and seven times more than the reference, respectively. This behaviour is related to the higher water loss of unconventional mortars due to their higher total porosity compared to the reference. In fact, Figure 5 reports the correlations found between shrinkage $(\varepsilon)$ at 40 days and total pore volume and between $\varepsilon$ at 40 days and water loss: the higher the total porosity and higher the shrinkage; the higher the water loss, the higher the shrinkage.
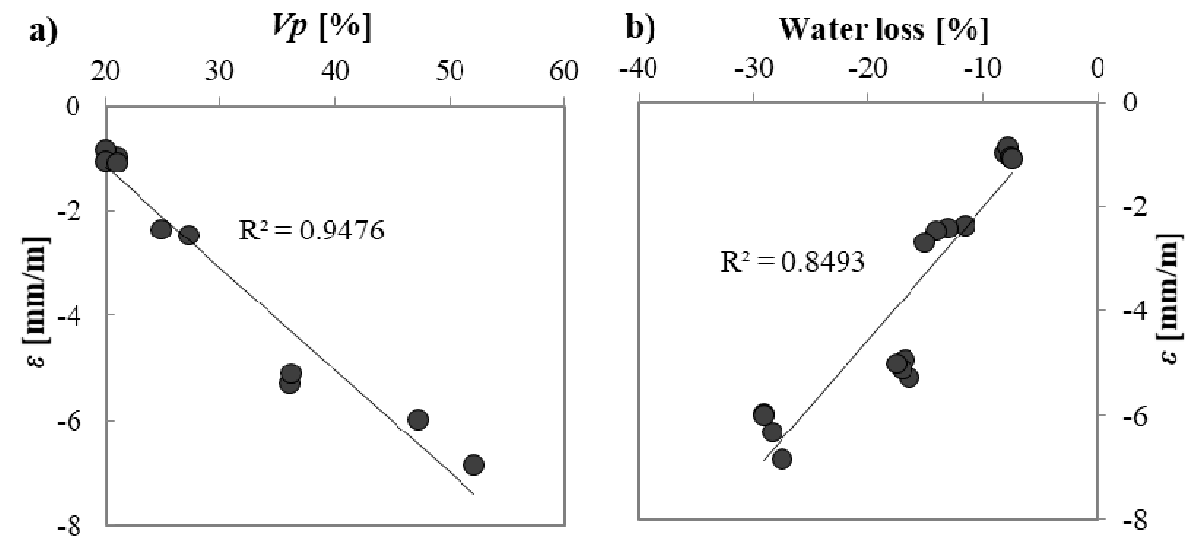

Figure 5. Correlation between (a) shrinkage and total porosity; (b) shrinkage and water loss of mortars. 
Drying shrinkage in mortars depends not only on the amount of total porosity but also on the dimension of pores [43]: the lower the pore radius, the higher the induced stress due to the evaporation of a certain amount of water. In this case, A1 and A2 mortars have the highest quantity of pores at small diameters (Figure 3). Despite A3 mortars having a lower quantity of pores with smaller diameters than the reference mortars, they have higher shrinkage due to the higher amount of total open porosity $V p$, which permits higher water evaporation.

Shrinkage is also related to the $E_{c}$ of mortars: the higher the $E_{c}$, the lower the value of shrinkage for a certain stress. Sand mortars have the highest $E_{c}$ value and, therefore, the lowest shrinkage value. A quite good linear correlation is found between shrinkage and calculated $E_{c}$ except for A1 mortars (out of trend dots in Figure 6) where the high $E_{c}$ is due to the high mechanical resistance, in spite of the high porosity (Tables 3 and 4).

There are no relevant changes in drying shrinkage due to different binders or the hydrophobic admixture.

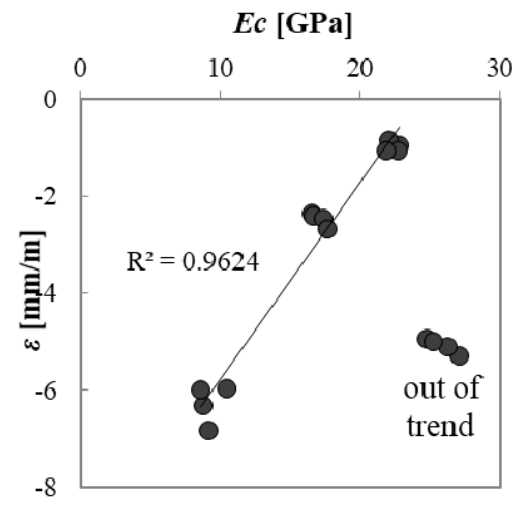

Figure 6. Correlation between drying shrinkage at 40 days and modulus of elasticity.

\subsection{Capillary Water Absorption}

Generally, as expected, the hydrophobic admixture is the main factor controlling the water uptake (Figure 7). The open porosity of mortars is the second most influential parameter: the higher the open porosity, the higher the water amount that can fill the pores. Therefore, the use of unconventional aggregates increases the water uptake of mortars due to their higher porosity, even if by a different amount (Table 4).

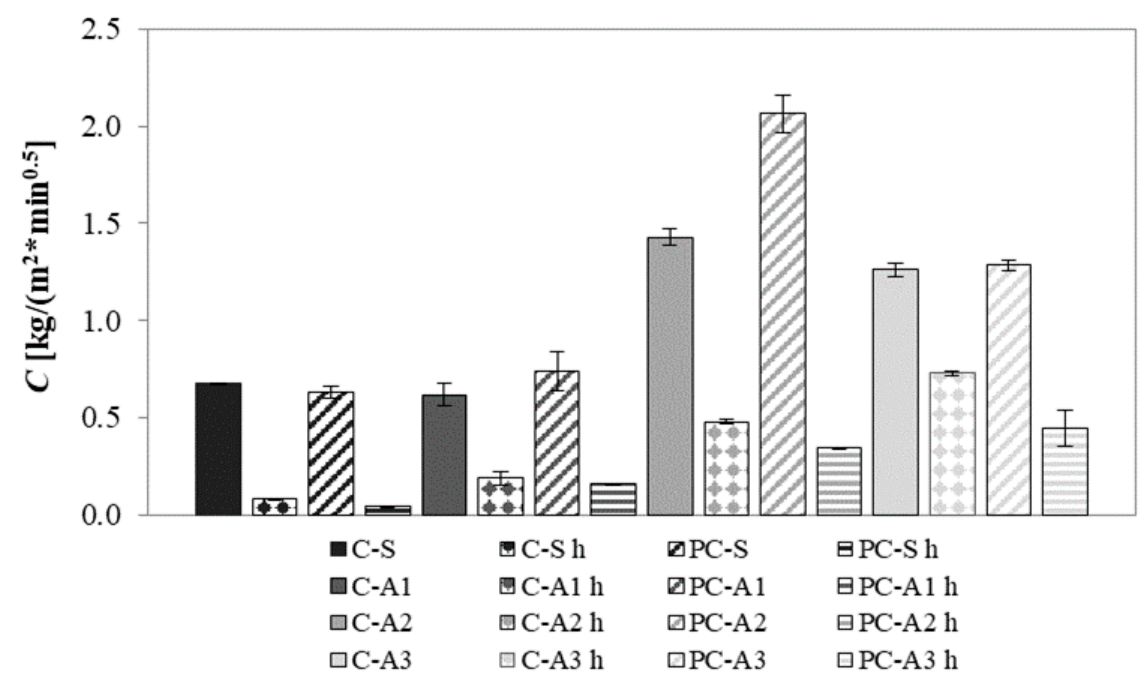

Figure 7. Capillary water absorption coefficient of mortars. 
The photocatalytic binder slightly increases water absorption: usually, hydrophilicity is given to mortars by $\mathrm{TiO}_{2}$ addition [44,45].

In sand mortars, the use of a hydrophobic admixture reduces more than eight times the water uptake. In mortars with unconventional aggregates, the effectiveness of the hydrophobic admixture is lower. This can be explained by the great specific surface of these mortars (Section 4.3) that cannot be well covered by the same quantity of silane.

In the case of A1 mortars, the water uptake is only slightly higher than that of sand mortars. The hydrophobic admixture reduces about four times the water uptake. A2 mortars absorb the highest quantity of water, three times higher than sand mortars, due to their higher porosity (Table 4). Moreover, A2 is a polar adsorbent and the great affinity of this type of adsorbent with water is well-known [46]. However, the use of a hydrophobic admixture decreases about five times the $C$ value. A3 mortars have a $C$ value two times higher than sand mortars. $A 3$ is a non-polar adsorbent but is not considered a hydrophobic material, since in saturation condition the water absorption is comparable to that of other hydrophilic materials [46]. Moreover, in spite of the A3 mortar total porosity (26\%) being lower than that of A1 mortars (36\%), capillary water absorption is higher due to the increased presence of larger pores. The initial (linear) phase of capillary water absorption corresponds to the filling of the larger capillary pores, while the second (non-linear) phase corresponds to the filling of the smaller pores $[47,48]$. Since a short time test $(90 \mathrm{~min})$ is used, large pores are more influential on capillary water absorption than small ones. In this case, the use of hydrophobic admixture decreases the $C$ value by about two times.

\subsection{Water Vapour Permeability}

Water vapour permeability results, expressed in terms of $\mu$ factor, are shown in Figure 8. Lower values of $\mu$ factor indicate higher values of permeability.

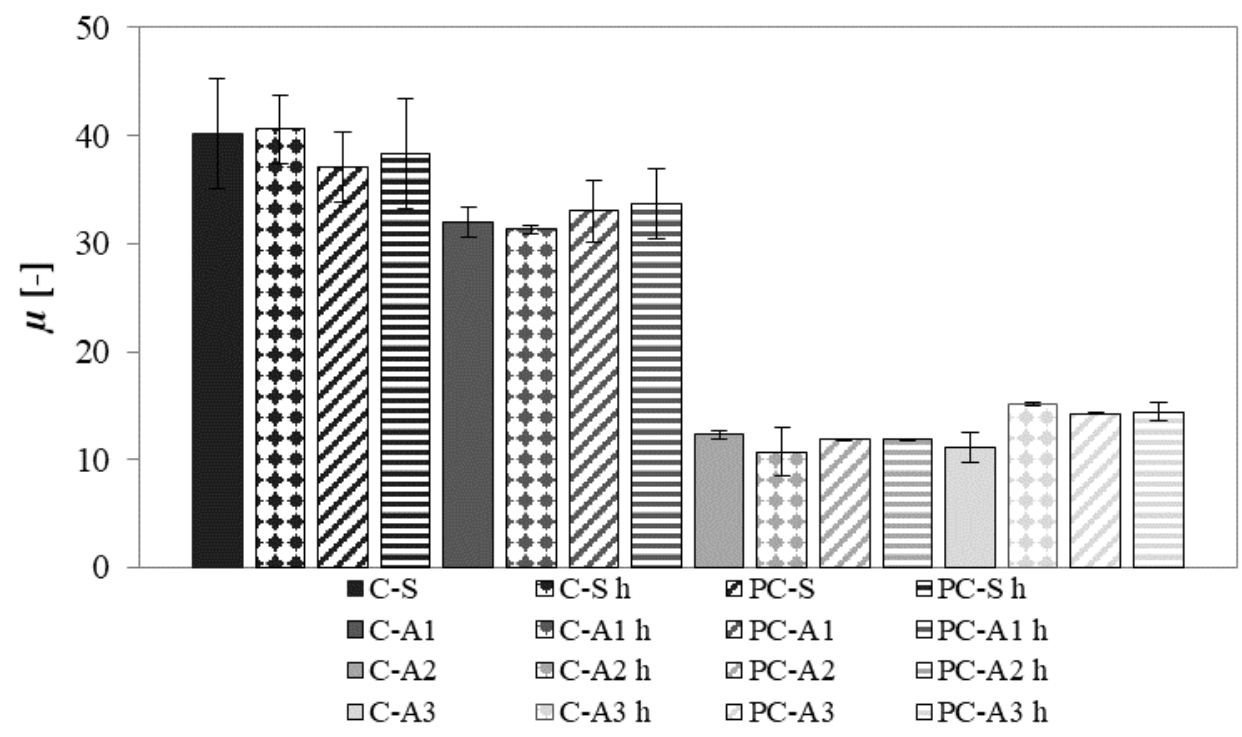

Figure 8. Water vapour resistance factor $\mu$ of mortars.

For all mortars, the use of photocatalytic or white cement and the hydrophobic admixture does not affect the results. The use of different aggregates is the main influencing factor.

Sand mortars have the highest value of $\mu$ meaning the lowest water vapour permeability. A1 mortars show $\mu$ value 20\% lower than the reference mortar. A2 and A3 mortars have a very low $\mu$ value, approximately $70 \%$ and $60 \%$ lower than that of sand mortars, respectively.

The permeability to water vapour depends on many factors, the principle in this case is the open porosity. Sand mortars are the less porous and less permeable to water vapour. However, 
according to Poiseuille's law, permeability depends not only on open porosity but also on pore size (permeability should be proportional to the product of porosity and square diameter of the main mode pore), connectivity, and tortuosity of the microstructure [49]. In particular, the greater the threshold pore diameter, the higher the permeability of the material [50]. A2 mortars are the most porous and A3 mortars have the largest pore diameters. These facts explain why A2 and A3 mortars are the most permeable, with $\mu$ comparable to those obtained in hemp-lime mortars $(\mu \sim 10)$ [51].

\subsection{Moisture Buffering Capacity}

Figure 9 shows the change in water vapour content $(\Delta \mathrm{m})$ normalised on the exposed surface of the specimens at different $\mathrm{RH}$ values.

a)

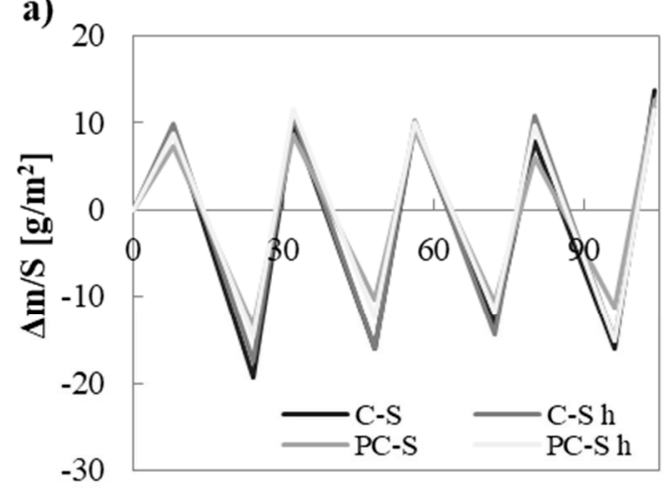

c) 20

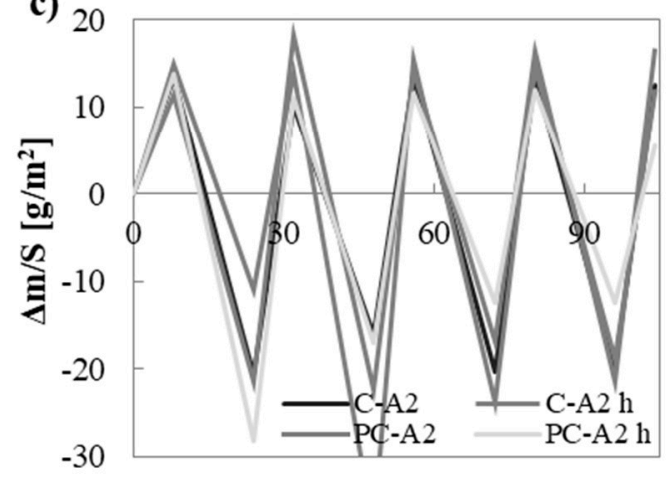

b)

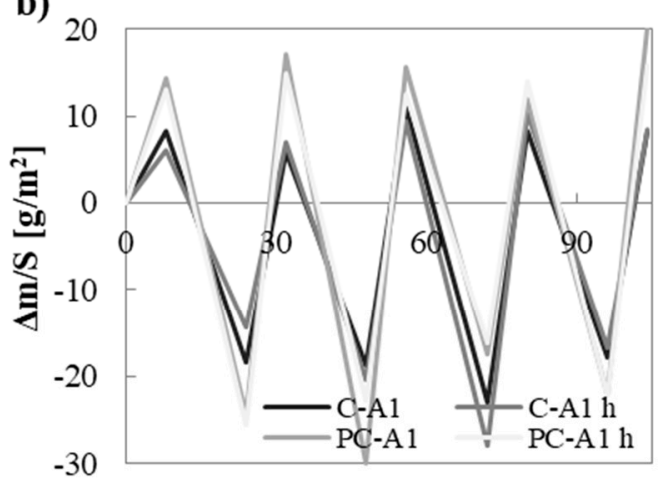

d)

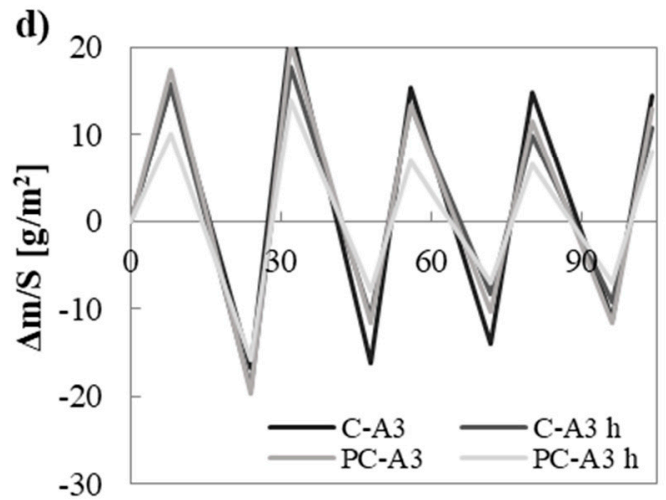

Figure 9. Change in water vapour content of mortars normalised on the surface of the specimens: (a) sand based mortars; (b) A1 based mortars; (c) A2 based mortars; (d) A3 based mortars.

The use of different binders or hydrophobic admixture does not affect this behaviour. On the contrary, the use of different aggregates is again the main influencing factor.

Sand mortars have the smallest exchange of water vapour. A1 and A2 mortars adsorb and desorb water vapour about two times more than sand mortars. A3 mortars have a slightly higher (about 20\%) capacity to adsorb/desorb water vapour than sand mortars.

The higher the specific surface of mortars, the higher is the ability of the material to uptake/release water vapour [52]. A2 mortars have the highest percentage of porosity and specific surface (Section 4.3) and show the best ability to change water both at low and high RHs [46] in terms of $M B V$ (Figure 10). Moreover, the great affinity of A2 polar adsorbent with water is well known. A2 mortars are followed by $\mathrm{A} 1$ and then $\mathrm{A} 3$ mortars. A1 mortars are less porous than A2 ones. Also, A3 mortars are less porous than A2. Moreover, A3 is a non-polar adsorbent, with lower affinity to polar molecules of water than $\mathrm{A} 1$ and $\mathrm{A} 2[46,53]$. 


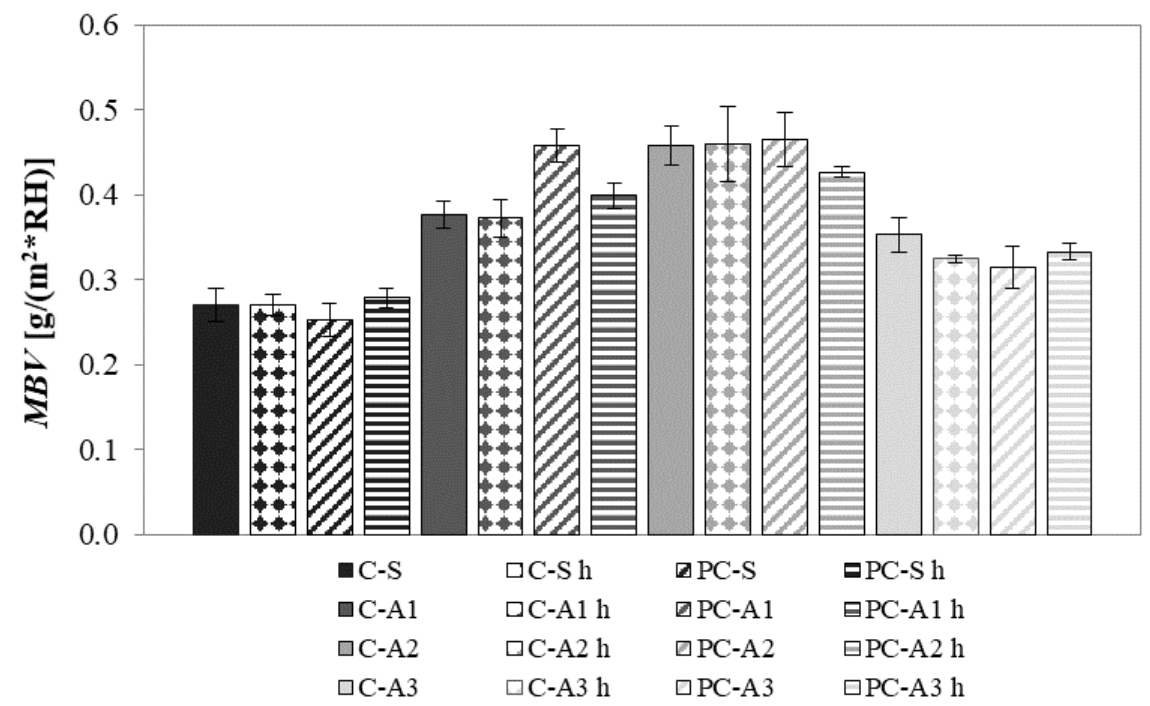

Figure 10. Moisture buffering value $(M B V)$ of mortars.

\subsection{Depolluting Properties}

\subsubsection{Continuous Flow Test}

Results of the photocatalytic efficiency of mortars, tested in terms of NO abatement under UVA radiation, are shown in Figure 11.

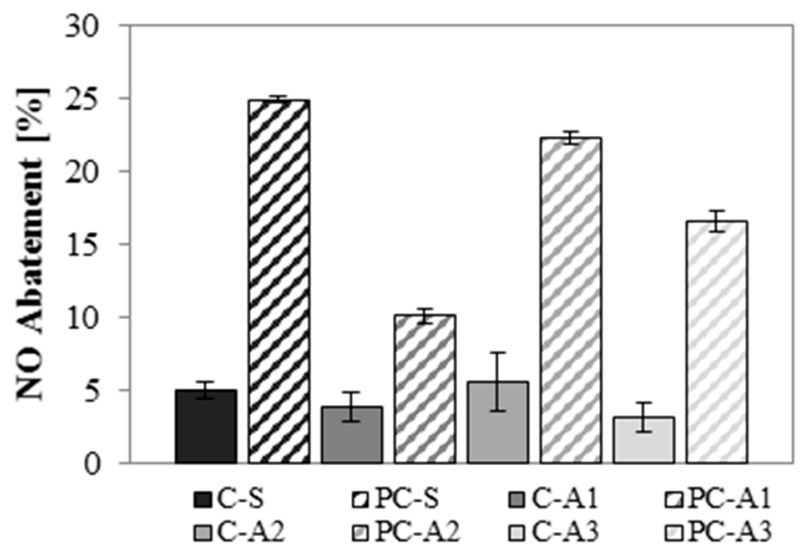

Figure 11. Photocatalytic efficiency under UVA radiation of mortars.

NO decomposes only in the presence of photocatalytic binder. The slight abatement of NO detected when white cement is used, is ascribed to the presence of a small amount of photocatalytic agent [54]. In this test, the adsorption process can be excluded: since the test starts when the stationary flux condition is reached, the substrate has enough exposure time to be saturated. With the same test, and adopting similar initial conditions of flux and NO concentration (550 ppb instead of 500 ppb), quite similar abatements (around 20\%) have been reported [25].

Sand mortars give the best NO abatement. However, A2 mortars show NO abatement comparable to that of sand mortars ( 22\%). A3 mortars reduce $\mathrm{NO}$ abatement by about $30 \%$ compared to the sand mortars. A3 aggregate has a black colour: dark colours could reduce the reflectance of radiation, increasing its absorption [55]. The worst interaction between the photocatalytic binder and unconventional aggregate is detected in A1 mortars, where the efficiency is about $40 \%$ of that measured in reference mortars. A1 is an adsorbent material with a high specific surface and high micro-porosity but it enhances the hydration products thanks to its pozzolanic activity (Section 4.3). 
New hydration products can increase compressive strength (Section 4.2) but can cover the active $\mathrm{TiO}_{2}$ sites [56], decreasing the photocatalytic efficiency of mortars.

\subsubsection{In Batch Test}

As example, Figure 12 reports the residual percentage of MEK inside the box with A1 mortars as a function of time, under dark conditions and under UVA radiation. The trend line starts at $20 \mathrm{~min}$ because this time is necessary for the complete vaporization of MEK (Section 3.8.2).

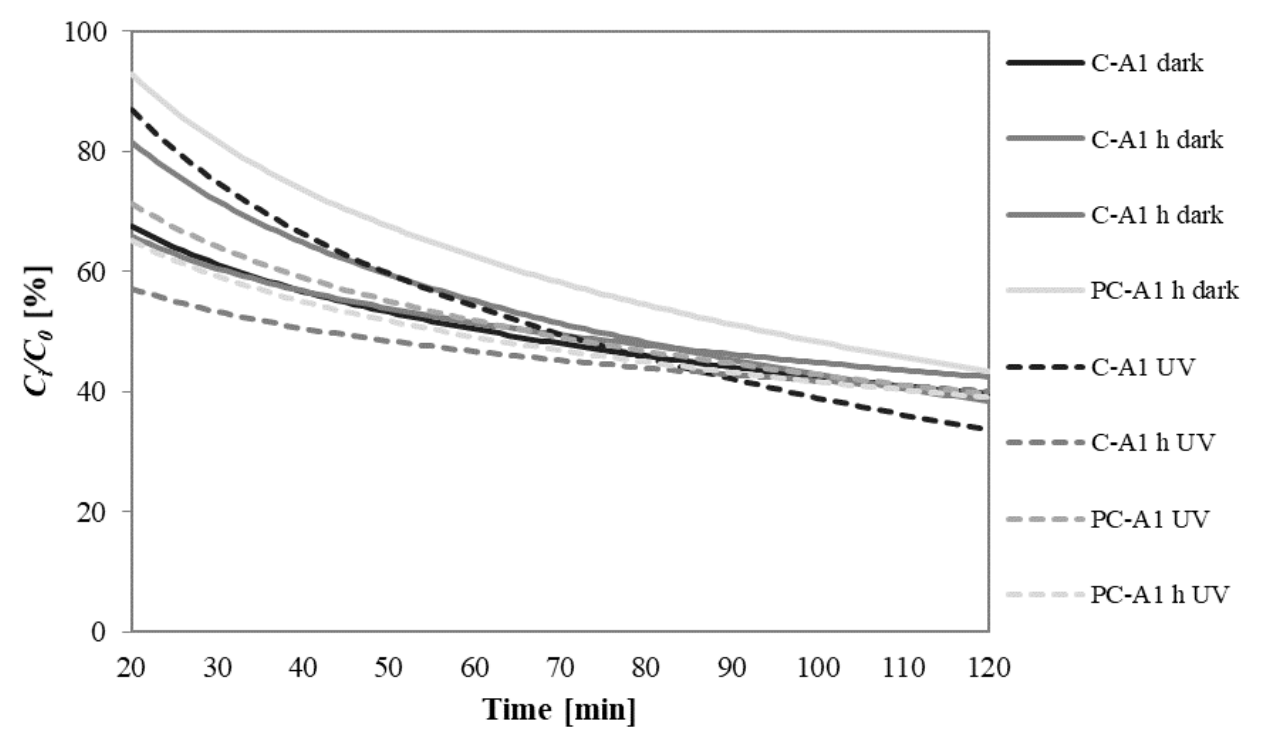

Figure 12. Methyl-ethyl-ketone (MEK) residual concentration inside the box as a function of time under dark conditions and under UVA radiation: A1 mortar.

To better compare the results, Figure 13 shows the MEK residual percentage inside the box with different mortars, performed under dark conditions and under UVA radiation, after 120 min testing.

The obtained values are comparable to those already reported in the literature with the same method [21,22]. Generally, the use of a hydrophobic admixture does not influence the depolluting properties of mortars. The main influencing factor is again the different typology of aggregates.

Sand mortars left $70 \%$ of MEK inside the box. In the presence of the photocatalytic binder, under UVA radiation, there is an increase in removal efficiency of about $15 \%$. A1 mortars, thanks to their high porosity, have almost a double depolluting capacity, with MEK residual of about $40 \%$. A2 and A3 mortars have depolluting capacity even four times higher than traditional sand mortars: the residual MEK concentration is only $20 \%$ after 120 min of test. These high efficiencies can be explained by the high specific surface of A2 mortars and with the great affinity of non-polar A3 aggregate with organic molecules as MEK [53,57].

In the presence of unconventional aggregates, no significant increase in MEK removal is observed in the presence of photocatalytic binder under UVA radiation. This means that the adsorption process of the aggregate predominates on the photocatalytic action of the binder under UVA radiation. 

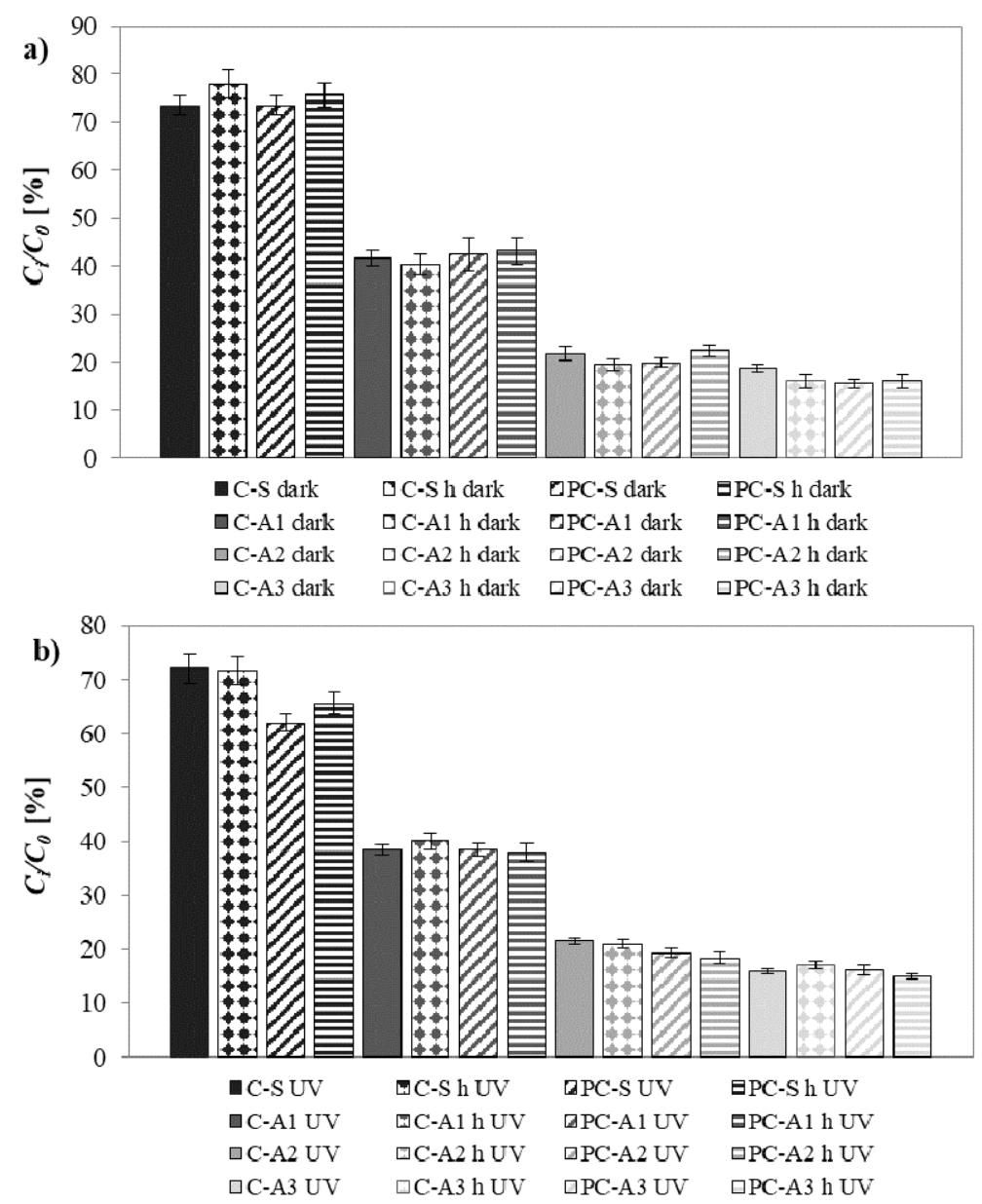

Figure 13. MEK residual concentration inside the box after 120 min testing: (a) under dark condition; (b) under UVA radiation.

\section{Conclusions}

New mortars for indoor renders or panels manufactured with three different types of lightweight unconventional aggregates (A1, A2, A3), in order to enhance their ability to passively improve IAQ, were studied. Unconventional aggregates fully replaced traditional calcareous sand by volume in cementitious mortars where white non-photocatalytic and photocatalytic cements were used as binders. To improve durability, the effect of a hydrophobic admixture on the properties of mortars was also discussed.

The obtained results show that the photocatalytic cement influences only the depolluting properties, while the hydrophobic admixture influences only the water absorption properties of the mortars.

Nevertheless, all the properties of the mortars were strongly influenced by the use of different aggregates. In particular, when conventional sand was replaced by volume with an unconventional aggregate in mortars, under the current tests methodologies:

- compressive strength decreases, except for A1 mortars where it even increases, but remains still acceptable for non-structural applications as renders;

- lightness is increased: A2 mortar can be classified as a lightweight mortar (density $\leq 1300 \mathrm{~kg} / \mathrm{m}^{3}$ );

- drying shrinkage increases, but it could be easily reduced by a shrinkage reducing admixture and/or an expansive agent;

- capillary water absorption increases but the hydrophobic admixture reduces it up to five times;

- permeability to water vapour increases up to $70 \%$ compared to the reference mortar; 
- moisture buffering capacity increases up to $65 \%$;

- depolluting capacity, in terms of MEK removal, increases up to $75 \%$.

No increase in MEK removal was observed in the presence of photocatalytic binder under UVA radiation meaning that, with these unconventional aggregates, the adsorption process of the aggregate predominates on the photocatalytic action of the binder.

Author Contributions: C.G. performed the materials characterization and the mix design of mortars. She tested the workability, the mechanical properties, the microstructure, the drying shrinkage, the capillary water absorption, the water vapor permeability and the moisture buffering capacity of mortars, and she analyzed and interpreted the relative data. She conducted and interpreted the in batch tests analysis and drafted the manuscript. M.P. performed the continuous flow test analysis and interpreted the continuous flow test data. A.M. interpreted the microstructure, the drying shrinkage, the capillary water absorption and the water vapor permeability data and edited the manuscript. M.L.R. supervised the tests to evaluate the depolluting properties of mortars (in batch tests analysis and continuous flow test), interpreted the relative data and edited the manuscript. F.T. coordinated and supervised the project, the analysis of the data and drafted and edited the manuscript. All authors read and approved the final manuscript.

Conflicts of Interest: The authors declare no conflict of interest.

\section{References}

1. Wang, S.; Yan, C.; Xiao, F. Quantitative energy performance assessment methods for existing buildings. Energy Build. 2012, 55, 873-888. [CrossRef]

2. Wells, E.M.; Berges, M.; Metcalf, M.; Kinsella, A.; Foreman, K.; Dearborn, D.G.; Greenberg, S. Indoor air quality and occupant comfort in homes with deep versus conventional energy efficiency renovations. Build. Environ. 2015, 93, 331-338. [CrossRef]

3. Aguado, S.; Polo, A.C.; Bernal, M.P.; Coronas, J.; Santamaría, J. Removal of pollutants from indoor air using zeolite membranes. J. Membr. Sci. 2004, 240, 159-166. [CrossRef]

4. Ozga, I.; Ghedini, N.; Giosuè, C.; Sabbioni, C.; Tittarelli, F.; Bonazza, A. Assessment of air pollutant sources in the deposit on monuments by multivariate analysis. Sci. Total Environ. 2014, 490. [CrossRef] [PubMed]

5. Fang, L.; Clausen, G.; Fanger, P.O. Impact of temperature and humidity on the perception of indoor air quality. Indoor Air 1998, 8, 80-90. [CrossRef]

6. Gonçalves, H.; Gonçalves, B.; Silva, L.; Raupp-Pereira, F.; Senff, L.; Labrincha, J.A. Development of porogene-containing mortars for levelling the indoor ambient moisture. Ceram. Int. 2014, 40, 15489-15495. [CrossRef]

7. Lelievre, D.; Colinart, T.; Glouannec, P. Hygrothermal behavior of bio-based building materials including hysteresis effects: Experimental and numerical analyses. Energy Build. 2014, 84, 617-627. [CrossRef]

8. Mensah-Attipoe, J.; Reponen, T.; Salmela, A.; Veijalainen, A.M.; Pasanen, P. Susceptibility of green and conventional building materials to microbial growth. Indoor Air 2015, 25, 273-284. [CrossRef] [PubMed]

9. WHO (World Health Organization). Development of WHO Guidelines for Indoor Air Quality. In Proceedings of the Report on a Working Group Meeting, Bonn, Germany, 23-24 October 2006; pp. 1-27. Available online: http: / /www.euro.who.int/_data/assets/pdf_file/0007/78613/AIQIAQ_mtgrep_Bonn_Oct06.pdf (accessed on 19 August 2017).

10. Kunkel, D.; Gall, E.; Siegel, J.A.; Novoselac, A.; Morrison, G.C.; Corsi, R.L. Passive reduction of human exposure to indoor ozone. Build. Environ. 2010, 45, 445-452. [CrossRef]

11. Lorencik, S.; Yu, Q.L.; Brouwers, H.J.H. Design and performance evaluation of the functional coating for air purification under indoor conditions. Appl. Catal. B Environ. 2015, 168, 77-86. [CrossRef]

12. Meininghaus, R.; Gunnarsen, L.; Knudsen, H.N. Diffusion and sorption of volatile organic compounds in building materials-Impact on indoor air quality. Environ. Sci. Technol. 2000, 34, 3101-3108. [CrossRef]

13. Vieira, J.; Senff, L.; Gonçalves, H.; Silva, L.; Ferreira, V.M.; Labrincha, J.A. Functionalization of mortars for controlling the indoor ambient of buildings. Energy Build. 2014, 70, 224-236. [CrossRef]

14. Di Giuseppe, E.; D'Orazio, M. Moisture buffering "active" devices for indoor humidity control: Preliminary experimental evaluations. Energy Procedia 2014, 62, 42-51. [CrossRef]

15. Ballari, M.M.; Hunger, M.; Hüsken, G.; Brouwers, H.J.H. NOx photocatalytic degradation employing concrete pavement containing titanium dioxide. Appl. Catal. B Environ. 2010, 95, 245-254. [CrossRef] 
16. Cárdenas, C.; Tobón, J.I.; García, C.; Vila, C. Functionalized building materials: Photocatalytic abatement of $\mathrm{NOx}$ by cement pastes blended with $\mathrm{TiO}_{2}$ nanoparticles. Constr. Build. Mater. 2012, 36, 820-825. [CrossRef]

17. Chen, J.; Poon, C.S. Photocatalytic cementitious materials: Influence of the microstructure of cement paste on photocatalytic pollution degradation. Environ. Sci. Technol. 2009, 43, 8948-8952. [CrossRef] [PubMed]

18. Munafò, P.; Quagliarini, E.; Goffredo, G.B.; Bondioli, F.; Licciulli, A. Durability of nano-engineered $\mathrm{TiO}_{2}$ self-cleaning treatments on limestone. Constr. Build. Mater. 2014, 65, 218-231. [CrossRef]

19. Horgnies, M.; Dubois-Brugger, I.; Gartner, E.M. NOx de-pollution by hardened concrete and the influence of activated charcoal additions. Cem. Concr. Res. 2012, 42, 1348-1355. [CrossRef]

20. Pierpaoli, M.; Giosuè, C.; Ruello, M.L.; Fava, G. Appraisal of a hybrid air cleaning process. Environ. Sci. Pollut. Res. 2017, 24, 12638-12645. [CrossRef] [PubMed]

21. Tittarelli, F.; Giosuè, C.; Mobili, A.; Ruello, M.L. Influence of binders and aggregates on VOCs adsorption and moisture buffering activity of mortars for indoor applications. Cem. Concr. Compos. 2015, 57. [CrossRef]

22. Giosuè, C.; Mobili, A.; Toscano, G.; Ruello, M.L.; Tittarelli, F. Effect of biomass waste materials as unconventional aggregates in multifunctional mortars for indoor application. Procedia Eng. 2016, 161, 655-659. [CrossRef]

23. Moriconi, G.; Tittarelli, F.; Corinaldesi, V. Review of silicone-based hydrophobic treatment and admixtures for concrete. Indian Concr. J. 2002, 76, 637-642. Available online: http:/ / cat.inist.fr/ ?aModele=afficheN\& cpsidt $=14431973$ (accessed on 19 January 2017).

24. Cucitore, R.; Cangiano, S.; Cassar, L. High Durability Photocatalytic Paving for Reducing Urban Polluting Agents. U.S. Patent 8,039,100 B2, 18 October 2011.

25. Folli, A.; Pade, C.; Hansen, T.B.; De Marco, T.; MacPhee, D.E. $\mathrm{TiO}_{2}$ photocatalysis in cementitious systems: Insights into self-cleaning and depollution chemistry. Cem. Concr. Res. 2012, 42, 539-548. [CrossRef]

26. Mobili, A.; Belli, A.; Giosuè, C.; Bellezze, T.; Tittarelli, F. Metakaolin and fly ash alkali-activated mortars compared with cementitious mortars at the same strength class. Cem. Concr. Res. 2016, 88. [CrossRef]

27. Demir, F. A new way of prediction elastic modulus of normal and high strength concrete-fuzzy logic. Cem. Concr. Res. 2005, 35, 1531-1538. [CrossRef]

28. Collepardi, M. The New Concrete; Grafiche Tintoretto: Treviso, Italy, 2006.

29. Corinaldesi, V.; Moriconi, G.; Tittarelli, F. Thaumasite: Evidence for incorrect intervention in masonry restoration. Cem. Concr. Compos. 2003, 25, 1157-1160. [CrossRef]

30. Silva, R.V.; de Brito, J.; Dhir, R.K. Performance of cementitious renderings and masonry mortars containing recycled aggregates from construction and demolition wastes. Constr. Build. Mater. 2016, 105, 400-415. [CrossRef]

31. Slanina, P.; Šilarová, Š. Moisture transport through perforated vapour retarders. Build. Environ. 2009, 44, 1617-1626. [CrossRef]

32. Abadie, M.O.; Mendonça, K.C. Moisture performance of building materials: From material characterization to building simulation using the Moisture Buffer Value concept. Build. Environ. 2009, 44, 388-401. [CrossRef]

33. Rode, C.; Peuhkuri, R.; Mortensen, L.H.; Hansen, K.K.; Time, B.; Gustavsen, A.; Ojanen, T.; Ahonen, J.; Svennberg, K.; Arfvidsson, J. Moisture buffering of building materials. In BYG DTU Report; Technical University of Denmark: Lyngby, Denmark, 2005. Available online: http:/ / orbit.dtu.dk/fedora/objects / orbit: 75984/datastreams / file_2415500/content (accessed on 19 August 2017).

34. Mazhoud, B.; Collet, F.; Pretot, S.; Chamoin, J. Hygric and thermal properties of hemp-lime plasters. Build. Environ. 2016, 96, 206-216. [CrossRef]

35. Methyl-Ethyl-Ketone (2-Butanone)_Hazard Summary, EPA U.S. Environmental Protection Agency. 2016. Available online: https:/ / www.epa.gov/sites/production/files/2016-09/documents/methyl-ethyl-ketone. pdf (accessed on 19 August 2017).

36. Tittarelli, F. Effect of low dosages of waste GRP dust on fresh and hardened properties of mortars: Part 2. Constr. Build. Mater. 2013, 47, 1539-1543. [CrossRef]

37. Carsana, M.; Tittarelli, F.; Bertolini, L. Use of no-fines concrete as a building material: Strength, durability properties and corrosion protection of embedded steel. Cem. Concr. Res. 2013, 48, 64-73. [CrossRef]

38. Branco, F.G.; Godinho, L. On the use of lightweight mortars for the minimization of impact sound transmission. Constr. Build. Mater. 2013, 45, 184-191. [CrossRef]

39. Pavlík, V.; Uzáková, M. Effect of curing conditions on the properties of lime, lime-metakaolin and lime-zeolite mortars. Constr. Build. Mater. 2016, 102, 14-25. [CrossRef] 
40. Lai, M.H.; Chu, R.Q.; Huang, H.C.; Shu, S.H.; Chung, T.W. Equilibrium isotherms of volatile alkanes, alkenes, and ketones on activated carbon. J. Chem. Eng. Data 2009, 54, 2208-2215. [CrossRef]

41. Lucas, S.S.; Ferreira, V.M.; De Aguiar, J.L.B. Incorporation of titanium dioxide nanoparticles in mortars-Influence of microstructure in the hardened state properties and photocatalytic activity. Cem. Concr. Res. 2013, 43, 112-120. [CrossRef]

42. Ruot, B.; Plassais, A.; Olive, F.; Guillot, L.; Bonafous, L. $\mathrm{TiO}_{2}$-containing cement pastes and mortars: Measurements of the photocatalytic efficiency using a rhodamine B-based colourimetric test. Sol. Energy 2009, 83, 1794-1801. [CrossRef]

43. Kumar, R.; Bhattacharjee, B. Porosity, Pore Size Distribution and In-situ Strength of Concrete. Cem. Concr. Res. 2003, 33, 155-164. [CrossRef]

44. Zhang, R.; Cheng, X.; Hou, P.; Ye, Z. Influences of nano- $\mathrm{TiO}_{2}$ on the properties of cement-based materials: Hydration and drying shrinkage. Constr. Build. Mater. 2015, 81, 35-41. [CrossRef]

45. Banerjee, S.; Dionysiou, D.D.; Pillai, S.C. Self-cleaning applications of $\mathrm{TiO}_{2}$ by photo-induced hydrophilicity and photocatalysis. Appl. Catal. B Environ. 2015, 176, 396-428. [CrossRef]

46. Yang, R. Gas Separation by Adsorption Processes; Butterworth Publisher: Oxford, UK, 1987.

47. Tittarelli, F.; Shah, S.P. Effect of low dosages of waste GRP dust on fresh and hardened properties of mortars: Part 1. Constr. Build. Mater. 2013, 47, 1532-1538. [CrossRef]

48. Benachour, Y.; Davy, C.A.; Skoczylas, F.; Houari, H. Effect of a high calcite filler addition upon microstructural, mechanical, shrinkage and transport properties of a mortar. Cem. Concr. Res. 2008, 38, 727-736. [CrossRef]

49. Silva, J.; de Brito, J.; Veiga, R. Incorporation of fine ceramics in mortars. Constr. Build. Mater. 2009, 23, 556-564. [CrossRef]

50. Katz, A.J.; Thompson, A.H. Quantitative prediction of permeability in porous rock. Phys. Rev. B 1986, 34, 8179-8181. [CrossRef]

51. Rahim, M.; Douzane, O.; Tran Le, A.D.; Promis, G.; Laidoudi, B.; Crigny, A.; Dupre, B.; Langlet, T. Characterization of flax lime and hemp lime concretes: Hygric properties and moisture buffer capacity. Energy Build. 2015, 88, 91-99. [CrossRef]

52. Wu, Y.; Gong, G.; Yu, C.W.; Huang, Z. Proposing ultimate moisture buffering value (UMBV) for characterization of composite porous mortars. Constr. Build. Mater. 2015, 82, 81-88. [CrossRef]

53. Somasundaran, P. Encyclopedia of Surface and Colloid Science. In Adsorption at Silica, Alumina, and Related Surfaces; CRC Press: Boca Raton, FL, USA, 2006. [CrossRef]

54. Cassar, L.; Pepe, C.; Tognon, G.; Guerrini, G.L.; Amadelli, R. White cement for architectural concrete, possessing photocatalytic properties. In Proceedings of the International Congress on the Chemistry of Cement, Durban, South Africa, 11-16 May 2003; pp. 2012-2021.

55. Chen, J.; Poon, C.S. Photocatalytic activity of titanium dioxide modified concrete materials-Influence of utilizing recycled glass cullets as aggregates. J. Environ. Manag. 2009, 90, 3436-3442. [CrossRef] [PubMed]

56. Chen, J.; Kou, S.C.; Poon, C.S. Photocatalytic cement-based materials: Comparison of nitrogen oxides and toluene removal potentials and evaluation of self-cleaning performance. Build. Environ. 2011, 46, 1827-1833. [CrossRef]

57. Wang, C.M.; Sen Chang, K.; Chung, T.W.; Wu, H. Adsorption equilibria of aromatic compounds on activated carbon, silica gel, and 13X zeolite. J. Chem. Eng. Data 2004, 49, 527-531. [CrossRef]

(c) 2017 by the authors. Licensee MDPI, Basel, Switzerland. This article is an open access article distributed under the terms and conditions of the Creative Commons Attribution (CC BY) license (http:/ / creativecommons.org/licenses/by/4.0/). 